\title{
O.P. Linnik
}

\section{SYNTHESIS AND CHARACTERIZATION OF NITROGEN AND

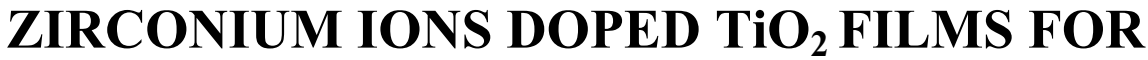 PHOTOCATALYTIC APPLICATION}

\author{
Chuiko Institute of Surface Chemistry of National Academy of Sciences of Ukraine \\ 17 General Naumov Str., Kyiv,03164,Ukraine,E-mail: okslinnik@yahoo.co.uk
}

\begin{abstract}
Codoped by nitrogen and zirconium ions titania thin films have been obtained by sol-gel and pulse laser deposition (PLD) methods to investigate the influence of zirconium ions as well as the synthesis procedure on the efficiency of nitrogen incorporation into semiconductive lattice that, in turns, effected on the film activity under ultraviolet and visible light. The composition of the films and the synthesis methods changed the optical properties of the materials as namely almost no effect of both doping agents on the band gap energy value was noted for the films obtained by pulse laser deposition technique, while its sharp narrowing was observed for nitrogen doped titania sol-gel sample. Additionally, the high absorption in the visible part of the spectra with the different maxima were registered for sol-gel films. Substitutional and interstitial nitrogen incorporation occurred in the case of sol-gel titania doped by both doping agents and only nitrogen, respectively. However, both types of nitrogen atoms were detected by X-ray photoelectron spectroscopy measurements for the laser deposited films and the relative intensity of its state was dependent whether single or double doping agents was used. Incorporation of each doping agent in titania matrix positively influenced on the photocatalytic activity of the sol-gel films under both ultraviolet and visible light. In the case of pulse laser deposited films, the presence of double doping agent stimulated the activity under UV light and the doping only by nitrogen led to the increase of photoactivity in visible light.
\end{abstract}

Keywords: nitrogen doped titania, zirconium ions, sol-gel method, PLD, photocatalysis

\section{INTRODUCTION}

Titania application is encircled as a photocatalyst in heterogeneous catalysis, for the production of hydrogen and electric energy in solar cells, as white pigments for cosmetic and paint industries, as a gas sensor, as an anticorrosive coating, as an optical coating, in electrical devices, in ceramics and others. The thin $\mathrm{TiO}_{2}$ films are extremely used as antireflective coatings, dielectric mirrors for lasers, metal mirrors with enhanced reflection, and filters. Despite high band gap energy of titania (about $3 \mathrm{eV}$ ), it is the most preferred photocatalyst and photoelectrode due to its high photo-corrosion resistance in aqueous media, chemical stability, low cost and nontoxicity. Given its indirect band gap transition, the anatase in comparison to rutile and brookite phases of $\mathrm{TiO}_{2}$ is the most preferred phase for photoassisted applications. Titania is a semiconductive material with band edges suitable for water oxidation reaction [1]. Several efforts are made to reduce titania band gap energy leading to its absorption of a larger portion of sunlight that reaches the surface of the earth. Non-metal doping agents (nitrogen, carbon, flour, sulfur i.e.) embedded in a semiconductor structure are responsible for visible light absorption by nanomaterials based on $\mathrm{TiO}_{2}$. Another approach to change the physical, optical, structural and photocatalytic properties of titania includes an employment of $d$-block metal ions (zinc, zirconium, iron, chromium, nickel, vanadium or copper). Modifications of $\mathrm{TiO}_{2}$ with such metals have extended the spectral response of $\mathrm{TiO}_{2}$ into the UV and visible region also improving photocatalytic activity [2,3]. However, the presence of transition metal ions in the semiconductive structure may also act as the recombination sites for photoformed an electron and a hole leading to the decrease in the quantum efficiency.

A number of key questions are still opened to summarize the properties and behavior of $\mathrm{N}-\mathrm{TiO}_{2}$ : i) the chemical nature of nitrogen atom (substitutional $\mathrm{N}_{\mathrm{s}}$ or interstitial $\mathrm{N}_{\mathrm{i}}$ ); ii) the electronic structure of the doped material and its influence on the change of the optical gap (band gap narrowing, impurity energy levels, oxygen vacancy); iii) the role of the nitrogen species in photocatalytic process. 
There are three different main opinions regarding modification mechanism of $\mathrm{TiO}_{2}$ doped with nonmetals. The first one is band gap narrowing: Asashi et al. [4] found that N2p state hybrids with $\mathrm{O} 2 p$ states in doped anatase. It caused their energies to be very close, and thus the band gap of $\mathrm{N}-\mathrm{TiO}_{2}$ was narrowed and capable to absorb visible light (Fig. $1 a$ ). The second one is the formation of impurity energy levels proposed by Irie et al. [5]. It is considered that oxygen sites in titania matrix substituted by nitrogen atoms form the isolated impurity energy levels above the valence band of semiconductor where irradiation with UV light excites electrons from both the VB and the impurity energy levels. However, the illumination with visible light only excites electrons from the impurity energy level (Fig. $1 b$ ). The third approach is the formation of oxygen vacancies proposed by Serpone et al. [6] where the commonality in the doped titania rests with formation of oxygen vacancies and the advent of color centers (e.g. $\mathrm{F}, \mathrm{F}^{+}, \mathrm{F}^{++}$, and $\mathrm{Ti}^{3+}$ ) that absorb the visible light radiation (Fig. $1 c$ ).

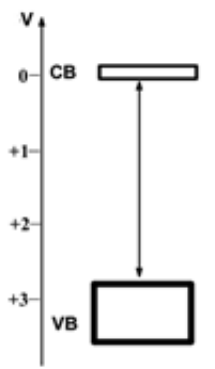

$a$

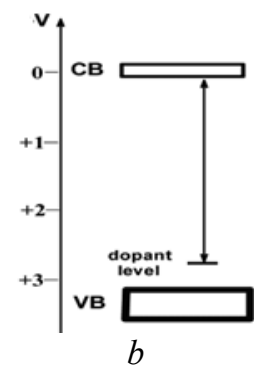

$b$

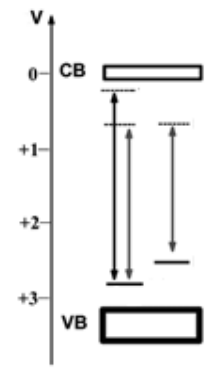

$c$

Fig. 1. Schematic representation of different electronic structure of doped titania

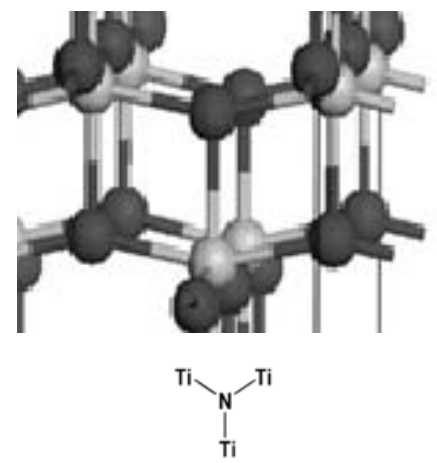

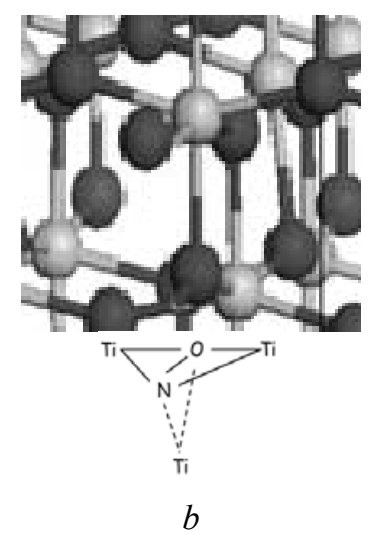

Fig. 2. Models for incorporated nitrogen: $a$ - substitutional nitrogen $(\mathrm{N} s)$ and $b$-interstitial nitrogen (Ni)

Table 1. Nitrogen bond types and their binding energy values taken from literature [7-14]

\begin{tabular}{lc}
\hline Bond type & Binding energy, eV \\
\hline \multicolumn{2}{c}{$\mathrm{N} 1 s$} \\
\hline $\mathrm{N}_{\mathrm{s}}$ & $\sim 396$ \\
$\mathrm{~N}_{\mathrm{i}}$ & $396-397$ \\
$\mathrm{NO}, \mathrm{NO}_{2}$ & $398-400$ \\
$\mathrm{NH}_{\mathrm{x}}, \mathrm{N}-\mathrm{C}$ & $400-403$ \\
\hline \multicolumn{2}{c}{} \\
\hline $\mathrm{Ti}-\mathrm{N}$ & $\mathrm{Ti} 2 p_{3 / 2}$ \\
$\mathrm{Ti}-\mathrm{O}$ & 456,457 \\
\hline
\end{tabular}

The nature of the nitrogen species responsible for the visible-light activity of nitrogen-modified titania is still under debate. The binding energy values for nitrogen and titanium species in the semiconductive matrix are summarized in Table 1. Most conclusions are based on the results of the XPS measurement of N1s binding energy values. Values of near $396 \mathrm{eV}$ and higher to $397 \mathrm{eV}$ are as signed to the formation of the bond corresponded to N-Ti-N bonds $[7,8]$ and O-Ti-N $[9,10]$, respectively. Higher energies of 400-401, 402-403, and even $407-408 \mathrm{eV}$ were proposed to correspond 
to $\mathrm{N}-\mathrm{N}, \mathrm{N}-\mathrm{O}$, or $\mathrm{N}-\mathrm{C}$ groups $[9,11]$, chemisorbed $\mathrm{N}_{2}$ [12] or $\mathrm{NO}_{\mathrm{x}}(x<2)$ and $\mathrm{NO}_{2}$ groups [13], respectively.

In overall, there is no definite opinion in the literature about the crucial points connected with the electronic structure of the doped semiconductor, the synthesis of high photocatalytic active materials under visible light, the chemical state of incorporated nitrogen in the metal oxide structure. The aim of this paper is to clarify the role of the presence of single and double doping agent in titania structure in the optical, electronic and photocatalytic characteristics of the materials; to estimate the efficiency of nitrogen incorporation in the pure and $\mathrm{Zr}$ ions doped $\mathrm{TiO}_{2}$ films obtained by sol-gel and PLD methods and the influence of synthesis conditions on the nature of incorporated nitrogen species; as well as to compare their photocatalytic properties.

\section{SOL-GEL AND PULSE LASER DEPOSITION SYNTHESIS OF MODIFIED TITANIA FILMS}

Nitrogen-doped titania can be obtained by the following methods: i) sputtering and implantation techniques, ii) calcination of undoped material under $\mathrm{N}$-containing atmosphere generated by nitrogen compounds like ammonia, amines, or urea, and iii) by sol-gel methods [14-16].

In a typical sol-gel process, inorganic metal salts or metal organic compounds (metal alkoxides) are used in the hydrolysis and polymerization reactions followed by sol formation. Complete polymerization and loss of solvent lead to the transition from the liquid sol into a solid gel phase (reactions 1-3).

$$
\begin{gathered}
\mathrm{M}(\mathrm{OR})_{\mathrm{n}}+\mathrm{H}_{2} \mathrm{O} \rightarrow \mathrm{M}(\mathrm{OR})_{\mathrm{n}-1}(\mathrm{OH})+\underset{\mathrm{ROH}}{\text { hydrolysis (1), }} \\
\mathrm{M}(\mathrm{OR})_{\mathrm{n}}+\mathrm{M}(\mathrm{OR})_{\mathrm{n}-1}(\mathrm{OH}) \rightarrow \begin{array}{c}
\mathrm{M}_{2} \mathrm{O}(\mathrm{OR})_{2 \mathrm{n}-2}+\mathrm{ROH} \\
\text { polymerization (2), }
\end{array} \\
\mathrm{M}(\mathrm{OR})_{\mathrm{n}}+\mathrm{n} / 2 \mathrm{H}_{2} \mathrm{O} \rightarrow \mathrm{MO}_{\mathrm{n} / 2}+\begin{array}{c}
\mathrm{nROH} \\
\text { total reaction (3), }
\end{array}
\end{gathered}
$$

where $M-\mathrm{Ti}$ and $\mathrm{Zr}, R$-organic species.

Thin films can be produced on a substrate by spin-coating or dip-coating. A wet gel will be formed with the following transformation to a dense ceramic. In the template method, organic templates are used for organizing network forming metal oxide species in nonaqueous solutions. The most commonly used organic templates are amphiphilic poly(alkylene oxide) block copolymers, such as Pluronic $\mathrm{P}-123$ $\mathrm{HO}\left(\mathrm{CH}_{2} \mathrm{CH}_{2} \mathrm{O}\right)_{20}\left(\mathrm{CH}_{2} \mathrm{CH}\left(\mathrm{CH}_{3}\right) \mathrm{O}\right)_{70}\left(\mathrm{CH}_{2} \mathrm{CH}_{2} \mathrm{O}\right)_{20} \mathrm{H}$.

Mesoporous pure and doped $\mathrm{TiO}_{2}$ thin films synthesized with the sol-gel technique using titanium tetraisopropoxide (TTIP) as the titania source and a three-block copolymer of polyethylene oxide and polypropylene oxide $(\mathrm{PEO})_{20}(\mathrm{PPO})_{70}(\mathrm{PEO})_{20}$ (PluronicP123 or P123) in alcoholic medium are reported in this paper. Concentrated $\mathrm{HClO}_{4}$ and acetylacetone (AcAc) were added to the precursor as stabilizers. The molar ratio of the components in the sol for films deposition was as following: TTIP : P123: AcAc : $\mathrm{H}_{2} \mathrm{O}: \mathrm{C}_{2} \mathrm{H}_{5} \mathrm{OH}: \mathrm{HClO}_{4}=1: 0.05: 0.5: 1: 40: 1$. A solution of urea in ethanol and/or zirconium propoxide $\left(\mathrm{Zr}\left(\mathrm{OCH}_{2} \mathrm{CH}_{2} \mathrm{CH}_{3}\right)_{4}\right)$ were added under vigorous stirring to obtain the sol contained 5 mol. \% both doping agents. The one-layered films were deposited by dip-coating procedure at a withdrawal rate $1.5 \mathrm{~mm} / \mathrm{s}$. The films were left for 1 hour for hydrolysis and heated in air at $450{ }^{\circ} \mathrm{C}$ for 1 hour with the heating rate of $3{ }^{\circ} \mathrm{C} / \mathrm{min}$ [16]. The key point during the $\mathrm{N}$ doped material synthesis is the temperature and rate of calcination. The heating has to be performed at lower temperature than $500{ }^{\circ} \mathrm{C}$ and at certain rate to prevent not only nitrogen release from the gel but also crystallization of anatase to rutile [17].

The pulsed laser deposition method of the film synthesis allows an easy doping or multilayer structures formation, a high purity compound formation, a fine control of thickness, the use of different types of the substrates, the various types of thin films (complex oxides, high-temperature superconducting, protective or ultrahard coatings, polymer or organic thin films) [18]. PLD is a physical vapour deposition process based on the vaporization of condensed matter by means of photons $[19,20]$. A high power pulsed laser beam is focused to strike a target of the desired composition. Material is then vaporized and deposited as a thin film on a substrate facing the target. This process can occur in ultrahigh vacuum or in the presence of a background gas. If the laser fluence exceeds a specific threshold, each tiny quantity of ablated material by a laser pulse is directed forward the deposition substrate, where the growing film is formed by recondensation [20]. In the most common set-up geometry, the collector is placed parallel to the target, at a certain distance and the laser pulses hit the target under $45^{\circ}$. The target is normally rotated in order to get uniform 
ablation of its surface, avoiding cracking, and thus obtaining a homogenous film. The obtained film may also be heated if a high degree of crystallinity:

$\mathrm{TiO}_{2} / \mathrm{ZrO}_{2}, \mathrm{~N}_{2}, \mathrm{CH}_{4}+h v($ laser $248 \mathrm{~nm}) \rightarrow$ $\rightarrow \mathrm{Ti}, \mathrm{Zr}, \mathrm{O}, \mathrm{N}, \mathrm{C}, \mathrm{H}$

vaporization (4)

$\mathrm{mTi}+\mathrm{m} \mathrm{O} \rightarrow \mathrm{m}(\mathrm{Ti}-\mathrm{O})$

deposition (5)

$\mathrm{mZr}+\mathrm{m} \mathrm{O} \rightarrow \mathrm{m}(\mathrm{Zr}-\mathrm{O})$

deposition (6)

$\mathrm{nTi}+\mathrm{nN} \rightarrow \mathrm{n}(\mathrm{Ti}-\mathrm{N})$

deposition (7)

$\mathrm{N}+\mathrm{O} \rightarrow \mathrm{NO}, \mathrm{C}+\mathrm{O} \rightarrow \mathrm{CO}, \mathrm{H}+\mathrm{O} \rightarrow \mathrm{HO}$

possible interactions (8).

PLD experiments were performed using a $\mathrm{KrF}^{*}$ laser source (COMPexPro 205 Coherent, $\tau \mathrm{FWHM} \leq 25 \mathrm{~ns}$ ). Pure $\mathrm{TiO}_{2}$ or 5 wt. $\% \mathrm{ZrO}_{2} / \mathrm{TiO}_{2}$ targets were laser ablated to grow coatings on glass plates. The films were synthesized at substrate temperatures of $450^{\circ} \mathrm{C}$. The samples were deposited at $100 \mathrm{~Pa}$ pressure in the atmosphere of $\mathrm{N}_{2}$ and $\mathrm{CH}_{4}$ with 5:1 ratio. The composition of the gas atmosphere was chosen to approach the synthesis conditions for both types of the films. It is known that the carbon species are still present in the structure of sol-gel films [21] after heating at $450{ }^{\circ} \mathrm{C}$, the presence of methane in dinitrogen in the ratio 1 to 5 was proposed.

\section{OPTICAL PROPERTIES OF THE FILMS}

The optical properties of the films were checked by means of the absorption spectra and calculated band gap energy values. It is clear that the optical properties of the films obtained by both methods are different. The PLD films exhibited the continues absorbance in the visible part of the spectrum. It must be noted that the blue shift of band edge of the curve for $\mathrm{N} / \mathrm{Zr} / \mathrm{TiO}_{2}$ film has occurred compared to $\mathrm{N} / \mathrm{TiO}_{2}$ one (Fig. 3). Among sol-gel titania films doped with different amount of urea, the film contained $5 \%$ of its showed the highest absorption intensity in the visible region and significant shift of absorption band edge to the longer wavelengths as well as the photocatalytic activity, this composition was chosen for the further investigation [16]. The UV-visible absorption measurements (Fig. 3) indicates that the sol-gel films noticeably absorb the visible light and have high absorbance, whereas the absorbance of PLD samples is much lower in this part of spectrum. The peaks with maximum at about 400 and $450 \mathrm{~nm}$ are observed for the sol-gel N/Zr/TiO and $\mathrm{N} / \mathrm{TiO}_{2}$ films (Fig. 3, curve 1 and 2), respectively. The difference in the position of these peaks could be attributed to the formation of the different nitrogen-containing species in the structure of the films. Thus, the presence of zirconium ions leads to the sharp change in optical properties of the photocatalysts.

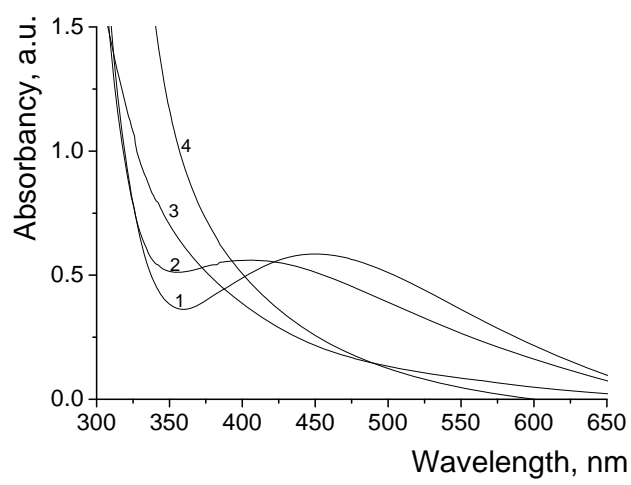

Fig. 3. Absorption spectra of sol-gel $\mathrm{N} / \mathrm{TiO}_{2}$ (1), $\mathrm{N} / \mathrm{Zr} / \mathrm{TiO}_{2}(2)$ and $\mathrm{PLD} \mathrm{N} / \mathrm{Zr} / \mathrm{TiO}_{2}(3), \mathrm{N} / \mathrm{TiO}_{2}$ (4) methods

The values of band gap energy $\left(\mathrm{E}_{\mathrm{bg}}\right)$ calculated by extrapolating the linear parts of the $(\alpha \mathrm{h} v)^{1 / 2} v s$ $f(h v)$ curves assuming an indirect electronic transition are presented in Fig. 4 and Table 2. The slight $\mathrm{E}_{\mathrm{bg}}$ increase of $\mathrm{Zr} / \mathrm{TiO}_{2}$ compared to $\mathrm{TiO}_{2}$ samples is explained by the presence of zirconium ions as a result of mutual Ti-O-Zr bond formation [22] or the decrease of the crystalline particle size, i.e. the quantum-size effect [23].

Table 2. The band gap energy values of $\mathrm{TiO}_{2}$ doped films synthesized by both methods

\begin{tabular}{ccc}
\hline $\mathbf{T i O}_{2}$ & \multicolumn{2}{c}{$\mathbf{E}_{\mathbf{b g},} \mathbf{e V}$} \\
\cline { 2 - 3 } doped film & $\mathbf{P L D}[21]$ & Sol-gel [16] \\
\hline $\mathrm{TiO}_{2}$ & 3.3 & 3.6 \\
$\mathrm{Zr} / \mathrm{TiO}_{2}$ & 3.4 & 3.7 \\
$\mathrm{~N} / \mathrm{TiO}_{2}$ & 3.3 & 3.3 \\
$\mathrm{~N} / \mathrm{Zr} / \mathrm{TiO}_{2}$ & 3.3 & 3.7 \\
\hline
\end{tabular}

When titania is doped by nitrogen, no significant change in $E_{b g}$ is observed for PLD films while its decrease to $3.3 \mathrm{eV}$ is noted for solgel sample. However, the increase in $\mathrm{E}_{\mathrm{bg}}$ value of sol-gel $\mathrm{N} / \mathrm{Zr} / \mathrm{TiO}_{2}$ pointed on the effect of zirconium ions. Hence, the electronic structure of 
the photocatalyst affects the optical characteristics of the films which, in turns, depend on the

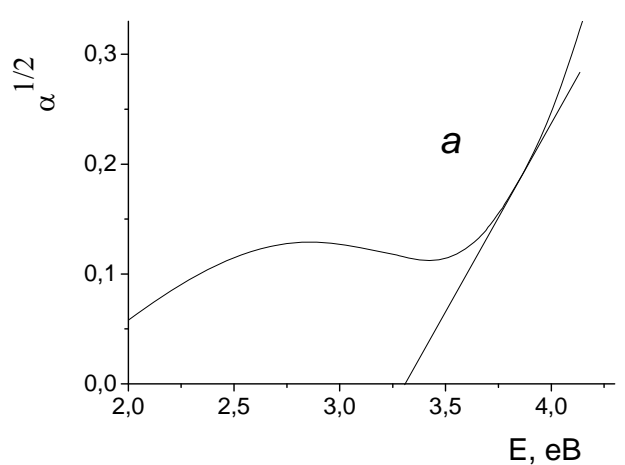

composition and the synthesis ways of the materials.

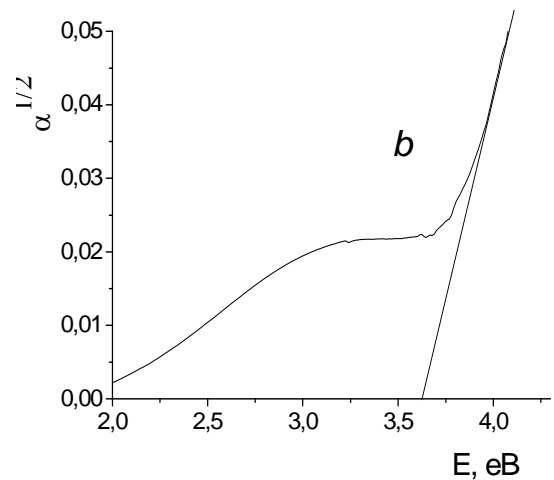

Fig. 4. The variation of $\alpha^{1 / 2}$ with excitation energy for sol-gel $\mathrm{N} / \mathrm{TiO}_{2}(a)$ and $\mathrm{N} / \mathrm{Zr} / \mathrm{TiO}_{2}(b)$ films

Considering the dependence of one second absorption coefficients vs excitation energy, the absorption thresholds at low excitation energy could be taken into account with the $E_{\mathrm{bg}}$ values equal to 1.5 and $2.0 \mathrm{eV}$ for $\mathrm{N} / \mathrm{TiO}_{2}$ and $\mathrm{N} / \mathrm{Zr} / \mathrm{TiO}_{2}$, respectively. Similar results are reported herein [24] where the three absorption thresholds in the $\alpha^{1 / 2} v s$ h $v$ curves were as signed to three possible compositions of modified titania films. The doping of nitrogen and carbon responsible for the band gap energies lower than $2 \mathrm{eV}$ was deduced. Analyzing the XPS N1s binding energy (see below) and the different positions of the absorption maximum for sol-gel $\mathrm{N} / \mathrm{TiO}_{2}$ and $\mathrm{N} / \mathrm{Zr} / \mathrm{TiO}_{2}$ films, it could be concluded that the optical properties of the materials are dependent on the type of incorporated nitrogen.

\section{ELECTRONIC STRUCTURES}

XPS is widely used to clarify the chemical state of elements and their surface ratio. There is no definite opinion about the XPS measurements of N1s binding energy where the values of $396-397 \mathrm{eV}$ are assigned to the N-Ti-N [8] or $\mathrm{O}-\mathrm{Ti}-\mathrm{N}$ bonds [9]. The formation of $\mathrm{N}-\mathrm{N}$ or $\mathrm{N}-\mathrm{C}$ or $\mathrm{N}-\mathrm{O}$ groups or chemisorbed dinitrogen is suggested at higher energies of $400-403 \mathrm{eV}[9,11,25]$. Nitrogen $1 s$ binding energies of 399.2 and $400.5 \mathrm{eV}$ are measured for a mixture of solid urea and $\mathrm{TiO}_{2}$ powder calcined at $400{ }^{\circ} \mathrm{C}$ corresponded to carbon nitrides $(399-400 \mathrm{eV}, \mathrm{C}=\mathrm{N}-\mathrm{C})$ and similar graphite-like phases $\left(400.6 \mathrm{eV}, \mathrm{N}-\mathrm{C}_{\mathrm{sp} 2}\right)$, and of polycyanogen $\left(399.0,400.5 \mathrm{eV}(-\mathrm{C}=\mathrm{N}-)_{\mathrm{x}}\right)$ [26].

$\mathrm{Ti} 2 p_{3 / 2}$ line of all sol-gel samples contains a single peak in the range of $459.2-459.4 \mathrm{eV}$ confirming the presence of $\mathrm{Ti}^{(\mathrm{IV})} \mathrm{O}_{2}$ [27]. The XPS
O1s peak in the range of $530-531 \mathrm{eV}$ corresponds to $\mathrm{O}^{2-}$ ions of crystalline oxide matrix. The presence of C-C (elemental carbon) bonds in the sol-gel structure is confirmed by $\mathrm{E}_{\mathrm{BE}}$ at $283.9 \mathrm{eV}$ [38]. $\mathrm{Zr} 3 d_{5 / 2}$ line with $E_{\mathrm{BE}}$ at $182.3 \mathrm{eV}$ is attributed to the $\mathrm{Zr}^{4+}$ ions surrounded by $\mathrm{O}^{2-}$ ions [28]. The $\mathrm{N} 1 s$ peak with the maximum at $396.0 \mathrm{eV}$ (Table 3) indicated the formation of substitutional nitrogen as namely Ti-N bonds in $\mathrm{N} / \mathrm{Zr} / \mathrm{TiO}_{2}$ while the $\mathrm{N} 1 s$ peak of $\mathrm{N} / \mathrm{TiO}_{2}$ films at $400.6 \mathrm{eV}$ could be related to the $\mathrm{N}-\mathrm{N}$ or $\mathrm{N}-\mathrm{C}, \mathrm{N}-\mathrm{O}$ or even chemisorbed dinitrogen species formation in $\mathrm{TiO}_{2}$ matrix $[11,25]$. Note that N1s binding energies of 399.1 and $400.5 \mathrm{eV}$ measured for modified by urea commercially available $\mathrm{TiO}_{2}$ powder were assigned to carbon nitrides $(399-400 \mathrm{eV}, \mathrm{C}=\mathrm{N}-\mathrm{C})$, graphite-like phases $\left(400.6 \mathrm{eV}, \mathrm{N}-\mathrm{Cs} p_{2}\right)$ and to polycyanogen $\left(399.0,400.5 \mathrm{eV}(-\mathrm{C}=\mathrm{N}-)_{\mathrm{x}}\right)$ [29]. It can be concluded that zirconium ions have an influence on the formation of rather substitutional nitrogen incorporated in the oxide matrix.

Table 3. XPS binding energy values and their relative intensities of sol-gel films [16]

\begin{tabular}{lcccc}
\hline \multirow{2}{*}{ Element } & \multicolumn{2}{c}{$\mathbf{N} / \mathbf{T i O}_{\mathbf{2}}$} & \multicolumn{2}{c}{$\mathbf{N} / \mathbf{Z r} / \mathbf{T i O}_{\mathbf{2}}$} \\
\cline { 2 - 5 } & $\boldsymbol{E}_{\mathbf{B E}}, \mathbf{e V}$ & $\begin{array}{c}\boldsymbol{I}, \\
\mathbf{\%}\end{array}$ & $\begin{array}{c}\boldsymbol{E}_{\mathbf{B E}}, \\
\mathbf{e V}\end{array}$ & $\begin{array}{c}\boldsymbol{I}, \\
\mathbf{\%}\end{array}$ \\
\hline $\mathrm{Ti} 2 p_{3 / 2}$ & 459.4 & 4.7 & 459.2 & 3.5 \\
$\mathrm{~N} 1 s$ & 400.6 & 0.6 & 396.0 & 0.4 \\
$\mathrm{O} 1 s$ & 530.9 & 20.5 & 530.7 & 23.8 \\
$\mathrm{C} 1 s$ & 283.9 & 73.1 & 283.7 & 71.8 \\
$\mathrm{Zr} 3 d_{5 / 2}$ & - & - & 182.7 & 0.5 \\
\hline
\end{tabular}

In the case of PLD films, the N1s line was deconvoluted into the four lines with the certain binding energy values. The intensity belonging to 
the substitutional $\mathrm{N}_{\mathrm{s}}$ lines at $395.8 \mathrm{eV}$ is increased for $\mathrm{N} / \mathrm{Zr} / \mathrm{TiO}_{2}$ in comparison with $\mathrm{N} / \mathrm{TiO}_{2}$ as clearly seen in Table 4 . In an opposite way, the intensity of binding energy at $397.8 \mathrm{eV}$ related to interstitial $\mathrm{N}_{\mathrm{i}}$ is higher for $\mathrm{N} / \mathrm{TiO}_{2}$. It is supposed that the peak at $399.2 \mathrm{eV}$ could be related to the N$\mathrm{C}$ formation and/or $\mathrm{N}_{2}$ adsorption onto the surface. The higher energy peak at $400.8 \mathrm{eV}$ is assigned to the formation of $\mathrm{N}_{2}$ or $\mathrm{NO}$ species (Fig. 5).

Significant peak intensity at $457.5 \mathrm{eV}$ assigned to the Ti-N bonds is observed for $\mathrm{N} / \mathrm{TiO}_{2}$ while the intensity of this peak for $\mathrm{N} / \mathrm{Zr} / \mathrm{TiO}_{2}$ is only $5 \%$. It is also attributed to the presence of $\mathrm{Ti}^{3+}$ states where such titanium species have oxidation states between +3 and +4 [30]. The peaks of Ti2 $2 p_{3 / 2}$ at 458.1 and $458.8 \mathrm{eV}$ belong to $\mathrm{Ti}^{4+}$ ions surrounded by oxygen ions. Similar to sol-gel films, the $\mathrm{Zr} 3 d_{5 / 2}$ line $\left(E_{\mathrm{BE}}=182.3 \mathrm{eV}\right)$ was recorded indicating the

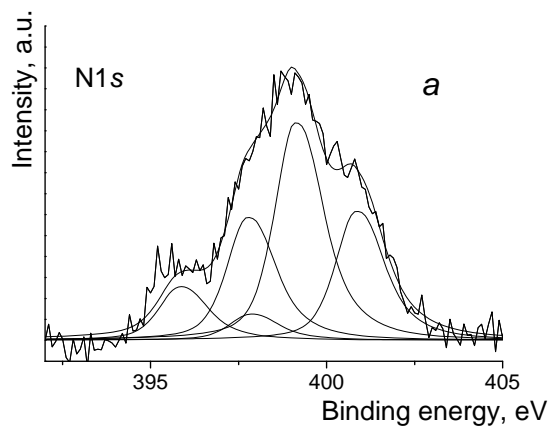

formation of $\mathrm{Zr}^{4+}$ ions surrounded by $\mathrm{O}^{2-}$ ions [31]. No signal pointing on the formation of Ti-O-Zr bonds is observed.

Table 4. $\mathrm{N} 1 s$ and $\mathrm{Ti} 2 p_{3 / 2}$ binding energy values and their relative intensities of PLD films [21]

\begin{tabular}{ccc}
\hline \multirow{2}{*}{ BE, eV } & N/TiO & N/Zr/TiO \\
\cline { 2 - 3 } & \multicolumn{2}{c}{$\mathbf{I , ~ \%}$} \\
\hline \multirow{3}{*}{$\mathbf{N 1 s}$} & \\
395.8 & 9.7 & $\mathbf{1 3 . 4}$ \\
397.8 & 27.4 & 18.1 \\
399.1 & 39.6 & 47.0 \\
400.8 & 23.3 & 21.5 \\
457.5 & $\mathbf{T i 2} \boldsymbol{p}_{\mathbf{3} / \mathbf{2}}$ & \\
458.1 & 24.4 & 5.1 \\
458.8 & 60.6 & 63.5 \\
\hline
\end{tabular}

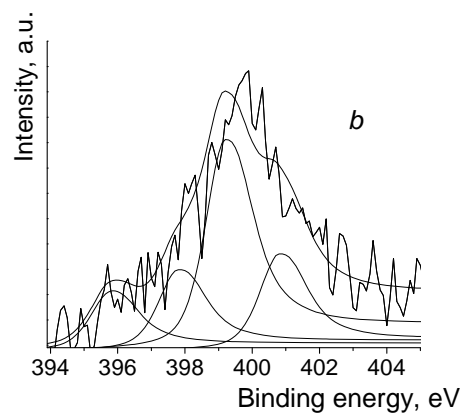

Fig. 5. XPS spectra of $\mathrm{N} 1 s$ region of $\mathrm{N} / \mathrm{TiO}_{2}(a)$ and $\mathrm{N} / \mathrm{Zr} / \mathrm{TiO}_{2}(b)$ synthesized by $\mathrm{PLD}$ method

\section{PHOTOCATALYTIC ACTIVITY}

Photocatalytic activity of the sol-gel films was assessed via tetracycline hydrochloride (TC) degradation. The film was immersed in $40 \mathrm{ml}$ of an aqueous solution of $2 \times 10^{-5} \mathrm{~mol} / \mathrm{L}$ TC. The reaction temperature was kept constant $\left(20^{\circ} \mathrm{C}\right)$ during the experimental procedure. The change of $\mathrm{TC}$ concentration was monitored with a Lambda 35 UV-Vis spectrophotometer (PerkinElmer) every 20 min at $\lambda=357 \mathrm{~nm}$. The film was immersed in the solution until complete adsorption in the dark occurred and then irradiated by $1000 \mathrm{~W}$ middlepressure mercury lamp for $90 \mathrm{~min}$. The distance lamp-reactor was set at $90 \mathrm{~cm}$. A blank experiment was carried out where a bare glass was used instead of film. No significant changes in the absorption spectra of the liquid were observed for the blank. For testing the visible light sensitivity, a filter transmitting light with $\lambda>380 \mathrm{~nm}$ was introduced in the photocatalytic setup [16].
Reduction of toxic dichromate ions was monitored via the photocatalytic activity of the PLD films. The detailed description of photocatalytic setup is given elsewhere [28]. The change of $\mathrm{Cr}(\mathrm{VI})$ ions concentration was monitored with a Lambda 35 UV-Vis spectrophotometer (Lambda 35, PerkinElmer) every $20 \mathrm{~min}$ at $\lambda=350 \mathrm{~nm}$. The reaction conversion means the percentage of photoreduced amount of $\mathrm{Cr}(\mathrm{VI})$ ions. The film was immersed in the solution until complete adsorption in the dark occurred, and then irradiated by $1000 \mathrm{~W}$ middle-pressure mercury lamp for $120 \mathrm{~min}$. The distance from lamp to reactor was set at $90 \mathrm{~cm}$. No significant changes in the absorption spectra of the liquid phase were observed for two blanks: dark condition and irradiation without film. A filter transmitting light with $\lambda>380 \mathrm{~nm}$ was introduced in the photocatalytic setup under visible light irradiation.

In the case of sol-gel films, the photocatalytic activity of $\mathrm{N} / \mathrm{TiO}_{2}$ films is increased in comparison 
with that of pure $\mathrm{TiO}_{2}$ film under both UV and visible light (Table 5). The highest activity under visible light is observed for the $\mathrm{N} / \mathrm{TiO}_{2}$ film (in three times higher than $\mathrm{TiO}_{2}$ ). The threefold increase in photocatalytic activity under UV light for $\mathrm{Zr} / \mathrm{TiO}_{2}$ films is noted as a result of the higher surface acidity leading to the better adsorption of TC molecules onto the surface compared to $\mathrm{TiO}_{2}$ film and the changed positions of the conduction and valence bands of the semiconductor $[23,6]$. Under visible light, no absorption by a semiconductor takes place and the photocatalytic process can only follow through i) an excitation of an electron from the additional $\mathrm{N}$-sublevels formed in the valence band of $\mathrm{TiO}_{2}$; ii) the excitation of $\mathrm{TC}$ molecule. As a result, TC can be degradated through a photoexcitation of TC molecule (indirect photocatalysis) and an excitation of the electron from the N-sublevels to $\mathrm{CB}$. The decrease in the photocatalytic activity is noted for $\mathrm{N} / \mathrm{Zr} / \mathrm{TiO}_{2}$ under visible light comparing with $\mathrm{N} / \mathrm{TiO}_{2}$ films suggesting the formation of the structure defects by double doping that makes easier the recombination process.

Table 5. The conversion level of TC destruction and dichromate reduction over the films under $\mathrm{UV}$ and visible light

\begin{tabular}{lcccc}
\hline Film & UV,\% & Vis., $\%$ & UV, $\%$ & Vis, \% \\
\hline & \multicolumn{2}{c}{ Sol-gel [16] } & \multicolumn{2}{c}{ PLD [21] } \\
\hline $\mathrm{TiO}_{2}$ & 11 & 5 & 24 & 3 \\
$\mathrm{~N}^{\mathrm{TiO}}{ }_{2}$ & 30 & 16 & 25 & 9 \\
$\mathrm{Zr} / \mathrm{TiO}_{2}$ & 29 & 11 & 20 & 2 \\
$\mathrm{~N} / \mathrm{Zr} / \mathrm{TiO}_{2}$ & 26 & 10 & 30 & 6 \\
\hline
\end{tabular}

Concerning PLD films, the $\mathrm{Zr} / \mathrm{TiO}_{2}$ film exhibits a lower activity under both UV and visible light compared with those of titania films (Table 5). The photocatalytic performance of the $\mathrm{N} / \mathrm{Zr} / \mathrm{TiO}_{2}$ film is the highest under UV and is lower under visible light than that of $\mathrm{N} / \mathrm{TiO}_{2}$. Thus, the highest conversion yield is obtained for $\mathrm{N} / \mathrm{Zr} / \mathrm{TiO}_{2}$ film under UV light suggesting the crucial role of zirconium ions as effective trapping sites for the photogenerated charges. However, these ions suppress the photoactivity when visible light is applied. It follows that the substitutional nitrogen (Ti-N) is basically responsible for the observed photoactivity under UV light as the higher percentage of it is noted for $\mathrm{N} / \mathrm{Zr} / \mathrm{TiO}_{2}$ film (Table 3), contrary to $\mathrm{N} / \mathrm{TiO}_{2}$, where the more interstitial nitrogen ions are formed suggesting their significant role in the photocatalysis under visible light. In particular, the interstitial $\mathrm{N}$ impurities give rise to the higher energy states in the gap, and might behave as stronger hole trapping sites, reducing the direct oxidation activity of the sample in the photocatalytic process [32].

\section{CONCLUSIONS}

Optical, electronic and photocatalytic properties of nitrogen doped semiconductive films based on titania synthesized by both sol-gel and PLD methods are opposed to clarify the key points responsible for photocatalytic activity under visible irradiation. It is certainly revealed that the nature of incorporated nitrogen in titania is strongly dependent on the nitrogen source and the synthetic procedure, even though the calcination temperature was $450^{\circ} \mathrm{C}$ for both methods and determines the optical properties of the material, as namely no significant change in band gap energy values is noted for PLD nitrogen doped titania films while the sharp narrowing of $E_{\mathrm{bg}}$ value is observed for the sol-gel samples. The difference in the position of $\mathrm{N} 1 s$ peaks is attributed to the formation of the different nitrogen containing species in the structure of the films. As shown by XPS results, no incorporation of $\mathrm{Zr}^{4+}$ ions in $\mathrm{TiO}_{2}$ lattice takes place for both methods, however, the presence of metal ions has an effect on the chemical state of nitrogen atoms (sol-gel method) and the efficiency of nitrogen incorporation (PLD method). Comparing the photocatalytic activity of the modified titania films synthesized by both methods, the increase in photoresponse under visible light is only noted for nitrogen-containing $\mathrm{TiO}_{2}$. Modification of sol-gel $\mathrm{TiO}_{2}$ by double doping agent leads to the fall in the photocatalytic activity indicating the enhancement of recombination rate caused by the presence of $\mathrm{Zr}^{4+}$ ions, while the presence of nitrogen and zirconium ions stimulates the activity under UV light in the case of pulse laser deposited films.

Acknowledgements. The author acknowledges the support of The Ministry of Education and Science of Ukraine under the contract M/30-2016. 


\title{
Синтез та характеристики $\mathrm{TiO}_{2}$, допованого йонами нітрогену та цирконію, для застосування у фотокаталізі
}

\author{
О.П. Ліннік \\ Інститут хімії поверхні ім. О.О. Чуйка Наиіональної академії наук України \\ вул. Генерала Наумова, 17, Київ, 03164, Україна, okslinnik@yahoo.co.uk
}

\begin{abstract}
Тонкі плівки діоксиду титану, допованого йонами нітрогену та цчирконію, були одержані золь-гель методом та методом лазерного переосадження. Показано, щзо оптичні властивості залежать від складу плівки та типу інкорпорованого нітрогену. Хімічний стан неметалу в структурі напівпровідника залежить від наявності йонів цирконію, як показано рентгено-фотоелектронною спектроскопією. Введення йонів нітрогену або ичирконію в структуру діоксиду титану позитивно впливає на фотокаталітичну активність під УФ та видимим світлом у випадку золь-гель плівок. Однак, наявність йонів як нітрогену, так $і$ изиконію сприяє підвищенню активності під УФ світлом, а модифікування тільки нітрогеном призводить до покращення фотокаталітичних властивостей під видимим світлом плівок, синтезованих методом лазерного переосадження.
\end{abstract}

Ключові слова: нітрогенвмісний діоксид титану, йони циикконію, золь-гель метод, метод лазерного переосадження

\section{Синтез и свойства $\mathrm{TiO}_{2}$, допированого ионами азота и циркония для применения в фотокатализе}

\author{
О.П. Линник \\ Институт химии поверхности им. А.А. Чуйко Наџиональной академии наук Украины \\ ул. Генерала Наумова, 17, Киев, Украина,03164,okslinnik@yahoo.co.uk
}

Тонкие пленки диоксида титана, допированного ионами азота и циркония, были получень золь-гель методом и методом лазерного переосаждения. Показано, что оптические свойства зависят от состава пленки и типа инкорпорированного азота. Химическое состояние неметалла в структуре полупроводника зависит от присутствия ионов циикония, как показывает рентгено-фотоэлектронная спектроскопия. Введение ионов азота или циркония в структуру диоксида титана положительно влияет на фотокаталитическую активность под УФ и видимым светом в случае золь-гель пленок. Однако, наличие ионов как азота, так и циркония способствует повышению активности под УФ светом, а модифицирование только азотом приводит к улучшению фотокаталитических свойств под видимым светом пленок, синтезированных методом лазерного переосаждения.

Ключевые слова: азотсодержащчий диоксид титана, ионы ичикония, золь-гель метод, метод лазерного переосаждения 


\section{REFERENCES}

1. Fujishima A., Honda K. Electrochemical photolysis of water at a semiconductor electrode. Nature. 1972. $238: 37$.

2. Czoska A.M., Livraghi S., Chiesa M., Giamello E., Agnoli S., Granozzi G., Finazzi E., Di Valentin C., Pacchioni G. The nature of defects in Fluorine-doped $\mathrm{TiO}_{2}$. J. Phys. Chem. C. 2008. 112(24): 8951.

3. Linnik O., Kisch H. On the mechanism of nitrogen fixation at nanostructured iron titanate films. Photochem. Photobiol. Sci. 2006. 5: 938.

4. Asahi R., Morikawa T., Ohwaki T. Visible-light photocatalysis in nitrogen-doped titanium dioxide. Science. 2001. 293(5528): 269.

5. IrieH., WatanabeY., HashimotoK. Nitrogen-concentration dependence on photocatalyticactivity of $\mathrm{TiO}_{2-\mathrm{x}} \mathrm{N}_{\mathrm{x}}$ powders. J. Phys. Chem. B. 2003. 107(23): 5483.

6. Serpone N. Is the band gap of pristine $\mathrm{TiO}_{2}$ narrowed by anion- andcation-doping of titanium dioxide in secondgeneration photocatalysts. J. Phys. Chem. B. 2006. 110(48): 24287.

7. Yin S., Ihara K., Aita Y.M., Sato K.T. Visible-light induced photocatalytic activity of $\mathrm{TiO}_{2-x} \mathrm{~A}_{y}(\mathrm{~A}=\mathrm{N}, \mathrm{S})$ prepared by precipitation route. J. Photochem. Photobiol. A. 2006. 179(1-2): 105.

8. Kobayakawa K., Murakami Y., Sato Y. Visible-light active N-doped $\mathrm{TiO}_{2}$ prepared by heating of titanium hydroxide and urea. J. Photochem. Photobiol. A. 2005. 170(2):177.

9. Cong Y., Zhang J., Chen F., Anpo M. Synthesis and characterization of nitrogen-doped $\mathrm{TiO}_{2}$ nanophotocatalyst with high visible light activity. J. Phys. Chem. C. 2007. 111(19): 6976.

10. Huang D., Liao S., Quan S., Liu L., He Z., Wan J., Zhou W. Synthesis and characterization of visible light responsive N-TiO2 mixed crystal by a modified hydrothermal process. J. Non-Cryst. Solids. 2008. 354(33): 3965.

11. Beranek R., Kisch H., Beranek R., Kisch H. Tuning the optical and photoelectrochemical properties of surfacemodified $\mathrm{TiO}_{2}$. Photochem. Photobiol. Sci. 2008. 7: 40.

12. Yuan J., Chen M., Shi J., Shangguan W. Preparation and photocatalytic hydrogen evolution of N-doped TiO $\mathrm{T}_{2}$ from urea and titanium tetrachloride. Int. J. Hydrogen Energy. 2006. 31(10): 1326.

13. Bacsa R., Kiwi J., Ohno T., Albers P., Nadtochenko V. Preparation, testing and characterization of doped $\mathrm{TiO}_{2}$ active in the peroxidation of biomolecules under visible light. J. Phys. Chem. B. 2005. 109(12): $5994-6003$.

14. Di V.C., Finazzi E., Pacchioni G., Selloni A., Livraghi S., Paganini M.C., Giamello E. N-doped TiO ${ }_{2}$ : Theory and experiment. Chem. Phys. 2007. 339(1-3): 44.

15. Emeline A.V., Kuznetsov V.N., Rybchuk V.K., Serpone N. Visible-light-active titania photocatalysts: the case of $\mathrm{N}$-doped $\mathrm{TiO}_{2}$ s-properties and some fundamental issues. Int. J. Photoenergy. 2008. 2008: Article ID 258394.

16. Shestopal N., Linnik O., Smirnova N. Influence of metal and non-metal ions doping on the structural and photocatalytic properties of titania films. Him. Fiz. Tehnol. Poverhni. 2015. 6(2): 203.

17. Fujishima A., Rao T.N., Tryk D.A. Titanium dioxide photocatalysis. J. Photochem. Photobiol. C. 2000. $1(1): 1$.

18. Ristoscu C., Mihailescu I.N. Biomimetic Coatings by pulsed laser deposition, chapter 7. In: «Laser Technology in Biomimetics». Basics and Applications, Series: Biological and Medical Physics, biomedical Engineering. (SpringerVerlag Heidelberg, New York, Dordrecht, London, 2013). P. 163.

19. Mihailescu I.N., Ristoscu C., Bigi A., Mayer I. Advanced biomimetic implants based on nanostructured coatings synthesized by pulsed laser technologies, Chapter 10. In «Laser-Surface Interactions for New Materials Production Tailoring Structure and Properties». Series: Springer Series in Materials Science. V. 130. 2010. P. 235.

20. Mihailescu I.N., Gyorgy E. Pulsed Laser Deposition: An Overview. In: International Trends in Optics and Photonics. (Heidelberg: Springer, 1999).

21. Linnik O., Shestopal N., Smirnova N., Eremenko A., Korduban O., Kandyba V., Kryshchuk T., Socol G., Stefan N., Popescu-Pelin G., Ristoscu C., Mihailescu I.N. Correlation between electronic structure and photocatalytic properties of non-metal doped $\mathrm{TiO}_{2} / \mathrm{ZrO}_{2}$ thin films obtained by pulsed laser deposition method. Vacuum. 2015.114: 166.

22. Gnatuk Yu., Smirnova N., Korduban O., Eremenko A. Effect of zirconium incorporation onthe stabilization of $\mathrm{TiO}_{2}$ mesoporous structure. Surf. Interface Anal. 2010. 42(6-7): 1276.

23. Smirnova N., Gnatyuk Yu., Eremenko A., Kolbasov G., Vorobetz V., Kolbasova I., Linyucheva O. Photoelectrochemical characterization and photocatalytic properties of mesoporous $\mathrm{TiO}_{2} / \mathrm{ZrO}_{2}$ films. Int. J. Photoenergy. 2006. Article ID 85469: 1.

24. Yang J., Bai H., Jiang Q., Lian J. Visible-light photocatalysis in nitrogen-carbon-doped $\mathrm{TiO}_{2}$ films obtained by heating $\mathrm{TiO}_{2}$ gel-film in an ionized $\mathrm{N}_{2}$ gas. Thin Solid Films. 2008. 516(8): 1736.

25. Kisch H., Sakthivel S., Janczarek M., Mitoraj D. A low-band gap, nitrogen-modified titania visible-light photocatalyst. J. Phys. Chem. C. 2007. 111(30): 11445.

26. Wang C.T., Wang, Lin J.C. Surface nature of nanoparticle zinc-titanium oxide aerogel catalysts. Appl. Surf. Sci. 2008. 254(15): 4500.

27. Alam M.J., Cameron D.C. Preparation and characterisation of $\mathrm{TiO}_{2}$ thin films by sol-gel method. J. Sol-Gel Sci. Technol. 2002. 25(2): 137. 
28. Linnik O., Petrik I., Smirnova N., Kandyba V., Korduban O., Eremenko A., Socol G., Stefan N., Ristoscu C., Mihailescu I.N., Sutan C., Malinovski V., Djokic V., Janakovic D. $\mathrm{TiO}_{2} / \mathrm{ZrO}_{2}$ thin films synthesized by PLD in low pressure N-, C- and/or O-containing gases: structural, optical and photocatalytic properties. Digest Journal of Nanomaterials and Biostructures. 2012. 7(3): 1343.

29. Mitoraj D., Kisch H. On the mechanism of urea-induced titania modification. Chemistry. 2010. 16(1): 261.

30. Chen H., Nambu A., Wen W., Graciani J., Zhong Z., Hanson J.C., Fujita E., Rodriguez J.A. Reaction of $\mathrm{NH}_{3}$ with Titania: N-doping of the oxide and TiN formation. J. Phys. Chem. C. 2007. 111(3): 1366.

31. Gnatyuk Yu., Smirnova N., Eremenko A., Ilyinl V. Design and photocatalytic activity of mesoporous $\mathrm{TiO}_{2} / \mathrm{ZrO}_{2}$ thin films. Adsorp. Sci. Technol. 2005. 23(6): 4978.

32. DiValentin C., Pacchioni G., Livraghi S.A.S., Giamello E. Characterization of paramagnetic species in $\mathrm{N}-\mathrm{doped}_{\mathrm{TiO}}$ powders by EPR spectroscopy and DFT calculations. J. Phys. Chem. B. 2005. 109(23):11414. 